\title{
CENTRAL AREOLAR MACULAR DYSTROPHY: A CASE REPORT AND REVIEW OF LITERATURE
}

\author{
Anurag Narula ${ }^{1}$, Shilpa Singh ${ }^{2}$, Sunil Chakravarty ${ }^{3}$, Sapna Chanana ${ }^{4}$
}

\section{HOW TO CITE THIS ARTICLE:}

Anurag Narula, Shilpa Singh, Sunil Chakravarty, Sapna Chanana. "Central Areolar Macular Dystrophy: A Case Report and Review of Literature". Journal of Evolution of Medical and Dental Sciences 2014; Vol. 3, Issue 24, June 16; Page: 6610-6612, DOI: 10.14260/jemds/2014/2789

ABSTRACT: PURPOSE: To report a case of Central Macular Areolar Dystrophy and to discuss the literature pertaining to it. METHODS: Clinical data including medical history, findings on physical examination and local examination were recorded for a 35years old male, case of Central Macular Areolar Dystrophy. No treatment was advised and patient was called for regular follow up to cater for low vision aids if required in the future. RESULTS: Best corrected Visual acuity of the patient remained constant at 6/36 for a period of one year with the patient being on 3monthly follow up. CONCLUSION: No particular or specific treatment is available for this rare macular dystrophy. The only modality available in the form of low vision aids for progressive disease.

KEYWORDS: Central Areolar Macular Dystrophy.

CASE HISTORY: A 35years old male, presented to us with headache, eye ache and loss of vision progressive deterioration since birth to the present status of vision being 6/36 (best corrected in both eyes).

General physical examination and systemic examination was unremarkable. On examination best corrected visual acuity was 6/36 both eyes, with normal anterior segment examination. On fundus examination an oval-to-round, atrophic, hypo pigmented area and area of well demarcated RPE atrophy was seen (figures 1 to 4). This area, on a fundus auto fluorescence (FAF) image, shows increased as well as decreased reflectivity resulting in a speckled FAF pattern.

Provisional Diagnosis: Central Macular Areolar Dystrophy.

No treatment was advised and patient was called for regular follow up to cater for low vision aids if required in the future.

Best corrected Visual acuity of the patient remained constant at $6 / 36$ for a period of one year with the patient being on 3 monthly follow up.

\section{DISCUSSION:}

Central Macular Areolar Dystrophy: Central areolar choroidal dystrophy (CACD) is a hereditary retinal disorder that affects the macula, resulting in progressive and usually profound visual loss. The hallmark feature of the disorder is a well-defined atrophy of the retinal pigment epithelium (RPE) and the choriocapillaris. ${ }^{1}$ Four clinical stages of the diseases have been described. ${ }^{2}$ In stage 1 CACD, subtle focal parafoveal pigmentary RPE changes can be observed on ophthalmoscopy. A typical stage 2 finding in the color image is an oval-to-round, mildly atrophic, hypopigmented area. This area, on a fundus autofluorescence (FAF) image, shows increased as well as decreased reflectivity resulting in a speckled FAF pattern. Stage 3 is characterized by one or more patches of well-demarcated RPE atrophy outside the fovea. In stage 4 , the atrophic area involves the fovea, resulting in a markedly decreased visual acuity. ${ }^{2,3}$ 
Autosomal dominant CACD is most commonly caused by mutations in the peripherin-2 (PRPH2) gene (formerly known as peripherin/RDS).4, 5 More than 90 different PRPH2 mutations associated with a wide spectrum of fundus alterations have been reported. To date, seven different mutations in the PRPH2 gene have been identified to cause the CACD phenotype.6-12 It may be challenging to diagnose CACD in the early stages of the disorder because of the relative nonspecific RPE abnormalities. Also, the late-onset variant may easily be confused with age-related macular degeneration (AMD) and thus be misdiagnosed.

\section{REFERENCES:}

1. Ashton N.Central areolar choroidal sclerosis; a histo-pathological study. Br J Ophthalmol. 1953; 37:140-147.

2. Hoyng CB, Deutman AF. The development of central areolar choroidal dystrophy. Graefes Arch Clin Exp Ophthalmol. 1996; 234:87-93.

3. Boon CJ, Klevering BJ, Cremers FP, et al. Central areolar choroidal dystrophy. Ophthalmology. 2009; 116:771-782.

4. Gamundi MJ, Hernan I, Muntanyola M, et al. High prevalence of mutations in peripherin/RDS in autosomal dominant macular dystrophies in a Spanish population. Mol Vis. 2007; 13: 10311037.

5. Hughes AE, Lotery AJ, Silvestri G. Fine localisation of the gene for central areolar choroidal dystrophy on chromosome 17p. J Med Genet. 1998; 35: 770-772.

6. Hoyng CB, Heutink P, Testers L, Pinckers A, Deutman AF, Oostra BA. Autosomal dominant central areolar choroidal dystrophy caused by a mutation in codon 142 in the peripherin/RDS gene. Am J Ophthalmol. 1996; 121: 623-629.

7. Kohl S, Christ-Adler M, Apfelstedt-Sylla E, et al. RDS/peripherin gene mutations are frequent causes of central retinal dystrophies. J Med Genet. 1997; 34: 620-626.

8. Nichols BE, Sheffield VC, Vandenburgh K, Drack AV, Kimura AE, Stone EM. Butterfly-shaped pigment dystrophy of the fovea caused by a point mutation in codon 167 of the RDS gene. Nat Genet. 1993; 3: 202-207.

9. Reig C, Serra A, Gean E, et al. A point mutation in the RDS-peripherin gene in a Spanish family with central areolar choroidal dystrophy. Ophthalmic Genet. 1995; 16: 39-44.

10. Schatz H. Diagnostic and therapeutic challenges. Retina. 2003; 23: 530-535.

11. Trujillo MJ, Bueno J, Osorio A, et al. Three novel RDS-peripherin mutations (689 delT, 857 del 17, G208D) in Spanish families affected with autosomal dominant retinal degenerations: mutations in brief no 147 online. Hum Mutat. 1998; 12: 70.

12. Yanagihashi S, Nakazawa M, Kurotaki J, Sato M, Miyagawa Y, Ohguro H. Autosomal dominant central areolar choroidal dystrophy and a novel Arg 195 Leu mutation in the peripherin/RDS gene. Arch Ophthalmol. 2003; 121: 1458-1461. 


\section{CASE REPORT}
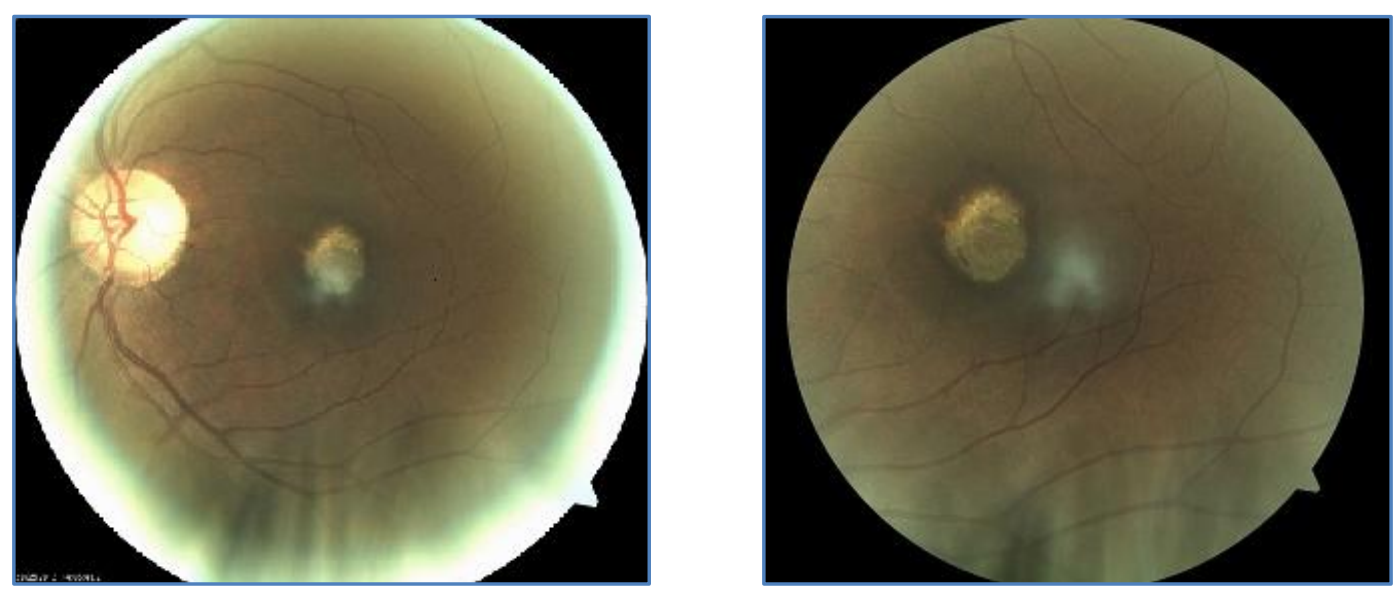

\section{FIGURE 1 AND 2 FUNDUS LESION OF RIGHT EYE}
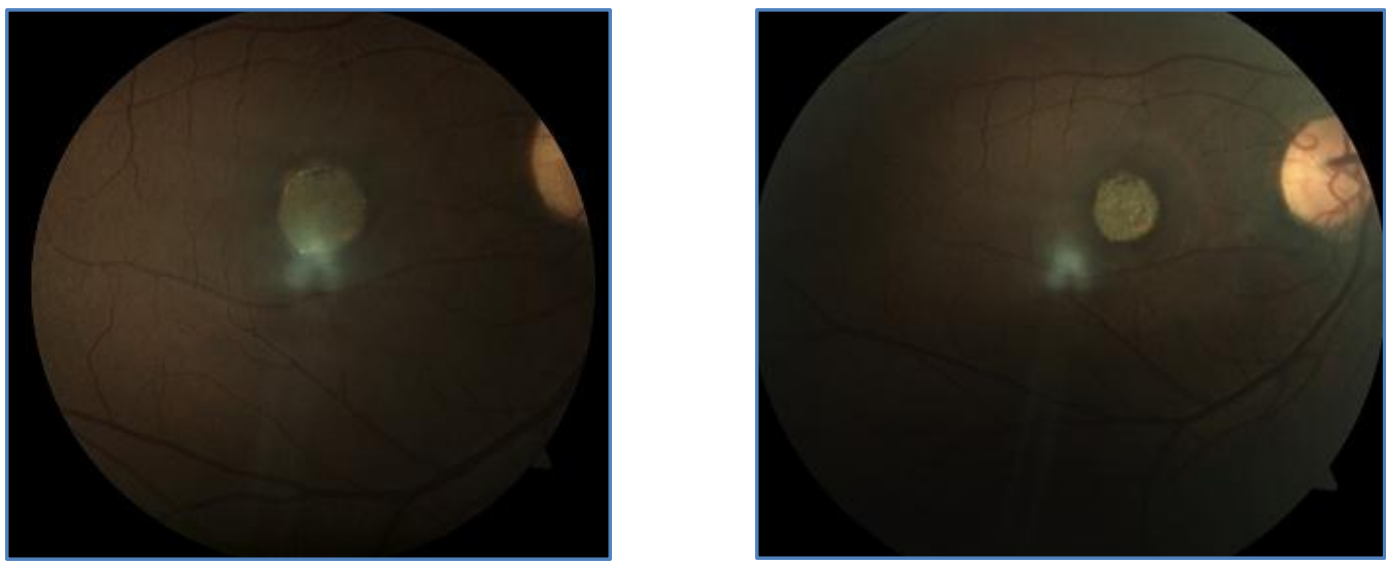

\section{FIGURE 3 AND 4 FUNDUS LESION OF LEFT EYE}

\section{AUTHORS:}

1. Anurag Narula

2. Shilpa Singh

3. Sunil Chakravarty

4. Sapna Chanana

\section{PARTICULARS OF CONTRIBUTORS:}

1. Senior Resident, Department of Ophthalmology, Attar Sain Jain Eye and General Hospital, Government of NCT of Delhi.

2. Senior Resident, Department of Ophthalmology, Attar Sain Jain Eye and General Hospital, Government of NCT of Delhi.

3. Consultant and HOD, Department of Ophthalmology, Attar Sain Jain Eye and General Hospital, Government of NCT of Delhi.
4. Medical Officer, Department of Ophthalmology, Attar Sain Jain Eye and General Hospital, Government of NCT of Delhi.

\section{NAME ADDRESS EMAIL ID OF THE CORRESPONDING AUTHOR:}

Dr. Anurag Narula,

D-II/368, Pandara Road,

New Delhi - 110003.

E-mail: ananuragnarula@rediffmail.com
Date of Submission: 10/05/2014.
Date of Peer Review: 12/05/2014.
Date of Acceptance: 02/06/2014.
Date of Publishing: 11/06/2014. 